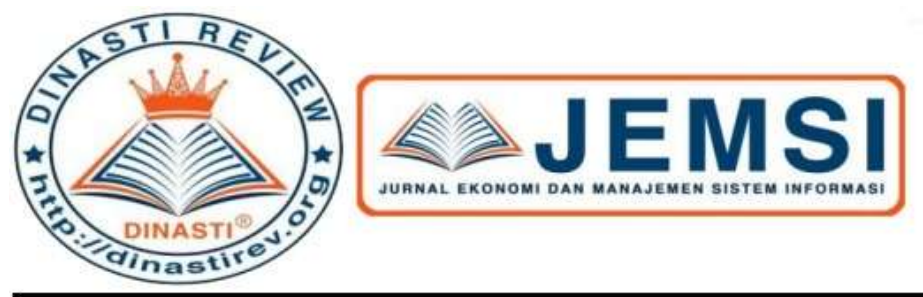

+62 878-9658-6407

087896586407 (ㅇ)

https://dinastirev.org/JEMSI (7)

editor@dinastirev.org@.

\title{
BUSINESS ETHIC \& GOOG CORPORATE GOVERNANCE (GCG) PADA PT BANK DANAMON INDONESIA Tbk
}

\author{
Ari Saputro \\ Program Pascasarjana, Universitas Mercubuana, Jakarta, Indonesia
}

\begin{abstract}
ARTICLE INFORMATION
Received: 15 November 2019

Revised: 20 November 2019

Issued: 23 November 2019

(filled in by Editor)
\end{abstract}

Corresponding author: first author

E-mail:

arisaputro14@gmail.com

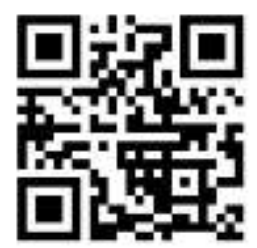

DOI:10.31933/JEMSI
Abstrak: Etika bisnis adalah suatu pengetahuan tentang tata cara ideal pengaturan dan pengelolaan bisnis yang memperhatikan norma dan moralitas yang berlaku secara universal. Kode etik PT Bank Danamon Indonesia Tbk merupakan nilai-nilai etika yang mengacu kepada visi, misi dan nilai-nilai budaya perusahaan yang dijunjung tinggi oleh perusahaan. Kode etik bertujuan untuk menjadi pedoman dalam berperilaku bagi seluruh Manajemen dan Pekerja PT Bank Danamon Indonesia Tbk dalam melaksanakan tugasnya sehari-hari, menjalin hubungan dengan nasabah, rekan sekerja dan pihak ketiga. Tata kelola perusahaan yang baik merupakan tata kelola perusahaan yang menjelaskan hubungan pihak-pihak yang berpartisipasi dalam pengelolaan dan kinerja perusahaan. Penerapan etika bisnis dan tata kelola perusahaan yang baik merupakan keharusan dan landasan penting bagi keberhasilan mewujudkan visi dan misi serta kelangsungan usaha perusahaan. Pelaksanaan prinsip-prinsip etika bisnis dan tata kelola perusahaan yang baik dianggap bisa membawa dampak positif terhadap keberlanjutan perusahaan. Kerangka kerja tata kelola perusahaan PT Bank Danamon Indonesia Tbk. telah dirancang untuk mencapai sukses jangka panjang dengan menjadi bank terbaik bagi nasabah dan menghasilkan keuntungan yang berkelanjutan bagi para pemegang saham. Metode penelitian yang digunakan adalah deskriptif. Penulisan deskriptif, yaitu penulisan yang berusaha untuk menuturkan pemecahan masalah yang ada sekarang berdasarkan data-data, menyajikan data, menganilisis dan menginterpretasi. Penulisan deskriptif bertujuan membuat deskripsi secara sistematis, faktual, dan akurat tentang fakta-fakta dan sifat-sifat populasi atau objek tertentu.

Kata Kunci: Etika Bisnis, Tata Kelola Perusahaan Yang Baik 


\section{PENDAHULUAN}

Penerapan Etika bisnis (Business Ethic) dan Good Corporate Governance (GCG) yang baik merupakan keharusan dan landasan penting bagi keberhasilan mewujudkan visi dan misi serta kelangsungan usaha perusahaan. Penerapan Etika bisnis dan Good Corporate Governance (GCG) saat ini tidak hanya sebagai pemenuhan kewajiban saja. Namun telah menjadi kebutuhan dalam menjalankan kegiatan bisnis perusahaan dalam rangka menjaga pertumbuhan usaha secara berkelanjutan, meningkatkan nilai perusahaan dan sebagai upaya agar perusahaan mampu bertahan dalam persaingan. Pelaksanaan prinsip-prinsip Etika Bisnis dan Good Corporate Governance (GCG) dianggap bisa membawa dampak positif terhadap keberlanjutan perusahaan. Juga dianggap penerapan prinsip-prinsipnya memberikan pengaruh baik bagi para stakeholders perusahaan dan lingkungan.

PT Bank Danamon Indonesia Tbk merupakan institusi keuangan yang keberadaan dan perannya diperhitungkan dalam industri perbankan khususnya dan perekonomian nasional pada umumnya. Dengan jumlah jaringan kerja yang menjangkau seluruh propinsi di Indonesia, serta jumlah unit kerja yang terus berkembang, PT Bank Danamon Indonesia Tbk mampu memainkan perannya dalam mendukung pertumbuhan sektor ekonomi maupun sosial baik melalui usaha penghimpunan dana, penyaluran dana serta layanan jasa perbankan lainnya serta melalui penyerapan tenaga kerja dalam jumlah yang signifikan.

Komitmen untuk terus menerus mengembangkan usahanya dan peran serta lebih dari tiga puluh ribuan karyawan, telah membuahkan berbagai keberhasilan dan penghargaan penting. Prestasi tersebut diraih tidak lepas dari kekuatan integritas, etika moral dari Para Pihak yang terus menerus diperbaiki dan dibangun. Keberhasilan tersebut tentu perlu dijaga kesinambungannya, oleh karena itu sejalan dengan perkembangan dunia usaha yang berubah secara cepat. Para Pihak perlu terus menerus melakukan penyesuaian baik dalam strategi bisnis maupun organisasi.

Dengan jumlah sumber daya manusia yang semakin besar, diperlukan pedoman bagi Para Pihak yang secara universal menjadi panduan dalam bertindak dan berperilaku dalam menjalankan fungsi tugas dan tanggung jawab masing-masing. Pedoman tersebut digali berdasarkan Visi, Misi, Nilai-Nilai Budaya Perusahaan, Etika Perbankan, ketentuanketentuan, serta Undang-Undang yang tertuang dalam Kode Etik. Para Pihak harus mengetahui, memahami, menghayati dan sepakat untuk menerapkan Kode Etik ini sebagai landasan moral, sikap dan etika dalam bertindak dan berperilaku. Demikian Kode Etik ini dibuat untuk kepentingan bersama demi kejayaan dan kemajuan PT Bank Danamon Indonesia Tbk.

Kode Etik PT Bank Danamon Indonesia Tbk merupakan nilai-nilai etika yang mengacu kepada visi, misi dan nilai-nilai budaya perusahaan yang dijunjung tinggi oleh perusahaan. Kode Etik bertujuan untuk menjadi pedoman dalam berperilaku bagi seluruh Manajemen dan Pekerja PT Bank Danamon Indonesia Tbk dalam melaksanakan tugasnya sehari-hari, menjalin hubungan dengan nasabah, rekan sekerja dan pihak ketiga. Kode Etik ini diharapkan mampu menunjang kelangsungan usaha serta menjaga nama baik PT Bank Danamon Indonesia Tbk.

Kode Etik merupakan satu kesatuan yang tidak terpisahkan dengan seluruh kebijakan PT Bank Danamon Indonesia Tbk dan Perjanjian Kerja Bersama. Manajemen dan Pekerja wajib mengetahui, memahami, dan melaksanakan Kode Etik serta kebijakan PT Bank Danamon Indonesia Tbk, Peraturan Bank Indonesia, Peraturan Otoritas Jasa Keuangan (OJK) 
dan peraturan perundang-undangan lainnya yang berlaku. Seluruh Pimpinan Unit Kerja wajib menjadi teladan dalam penerapan Kode Etik dalam unit kerja yang dipimpinnya. Kode Etik bersifat mengikat dan oleh karenanya pelanggaran Kode Etik dapat dikenakan sanksi, baik yang sifatnya administratif, perdata maupun pidana sesuai dengan prosedur dan ketentuan yang berlaku. Pihak yang mengetahui adanya pelanggaran Kode Etik, namun tidak melaporkan, dianggap melakukan pelanggaran Kode Etik.

PT Bank Danamon Indonesia Tbk berkomitmen dalam mencapai keberhasilan jangka panjang untuk bisnis perusahaan dengan menjadi bank terbaik bagi nasabah dan menghasilkan keuntungan yang stabil dan berkelanjutan bagi pemangku kepentingan serta mampu memberikan nilai lebih bagi seluruh para pemangku kepentingan. Danamon mengakui bahwa standar tinggi tata kelola perusahaan dan kepatuhan pada hukum dan perundang-undangan merupakan strategi utama untuk mencapai hal ini.

Tata kelola perusahaan yang baik (Good Corporate Governancel GCG) sangat penting bagi PT Bank Danamon Indonesia Tbk dalam mewujudkan visi yang strategis untuk menjadi mitra yang amanah dan profesional bagi para pemangku kepentingan. PT Bank Danamon Indonesia Tbk percaya bahwa tata kelola perusahaan yang memenuhi standar internasional yang tinggi secara signifikan meningkatkan kepercayaan masyarakat kepada Bank. Transparansi, akuntabilitas, tanggung jawab, independensi, dan keadilan/kesetaraan merupakan prinsip tata kelola PT Bank Danamon Indonesia Tbk. Unsur-unsur ini memastikan bahwa kontrol dan pengawasan yang diperlukan untuk manajemen risiko yang efektif, sesuai dengan semua hukum dan peraturan yang relevan, dan pengungkapan informasi yang akurat dan lengkap kepada public/pasar berfungsi dengan baik.

PT Bank Danamon Indonesia Tbk meninjau praktik tata kelola perusahaan yang diterapkan dan berusaha untuk memenuhi persyaratan yang relevan dari praktik terbaik tata kelola perusahaan internasional dan nasional dari waktu ke waktu. Pihak Bank melakukan penilaian internal dan eksternal untuk memantau pelaksanaan GCG dari lima prinsip GCG PT Bank Danamon Indonesia Tbk. Selain itu, perusahaan melaporkan dan menerbitkan Laporan Tahunan dan Laporan Keberlanjutan yang komprehensif. PT Bank Danamon Indonesia Tbk senantiasa berusaha untuk patuh pada dan memenuhi standar tata kelola nasional, regional dan internasional melalui laporan yang diterbitkan secara transparan.

\section{KAJIAN PUSTAKA}

Etika bisnis (Business Ethic) adalah suatu pengetahuan tentang tata cara ideal pengaturan dan pengelolaan bisnis yang memperhatikan norma dan moralitas yang berlaku secara universal, Muslich (2004). Etika merupakan nilai-nilai tingkah laku atau aturan-aturan tingkah laku yang diterima oleh suatu golongan tertentu atau individu, Floyd (2013). Hal-hal yang harus diketahui dalam menciptakan etika bisnis yaitu:

1. Menuangkan ke dalam hukum positif, perlunya sebagian etika bisnis dituangkan dalam suatu hukum positif yang menjadi peraturan perundang-uandangan dimaksudkan untuk menjamin kepastian hukum dari etika bisnis tersebut, seperti "proteksi" terhadap pengusaha lemah.

2. Mampu menyatakan yang benar itu benar, kalau pelaku bisnis itu memang tidak wajar untuk menerima kredit (sebagai contoh) karena persyaratan tidak bisa dipenhi dan jangan memaksa diri untuk mengadakan "kolusi" serta memberikan "komisi" kepada pihak yangt terkait. 
3. Pengembangan tanggung jawab sosial (social responsibility), pelaku bisnis dituntut untuk peduli denngan keadaan masyarakat.

4. Memelihara kesepakatan bersama atau menumbuhkembangkan kesadaran dan rasa memiliki terhadap hal-hal yang teah disepakatu adalah salah satu usaha menciptakan etika bisnis.

Corporate Governance adalah sistem yang mengatur dan mengendalikan perusahaan yang menciptakan nilai tambah (value added) untuk semua stakeholders. Good corporate governance merupakan tata kelola perusahaan yang menjelaskan hubungan pihak-pihak yang berpartisipasi dalam pengelolaan dan kinerja perusahaan, Monks (2003). Tata kelola Perusahaan yang Baik (Good Corporate Governancel GCG) merupakan konsep yang diajukan demi peningkatan kinerja perusahaan melalui supervisi atau monitoring kinerja manajemen dan menjamin akuntabilitas manajemen terhadap stakeholder dengan mendasarkan pada kerangka peraturan, Nasution, (2007). Ada banyak cara yang harus dilakukan oleh suatu perusahaan untuk dapat berkembang dan mendapatkan keuntungan yang maksimal, salah satu diantaranya yaitu dengan memiliki tata kelola perusahaan yang baik (good corporate governance), Muchtar (2013).

Untuk itu dapat disimpulkan bahwa Good Corporate Governance (GCG) merupakan suatu sistem yang didalam pelaksanaannya terdapat proses untuk mengendalikan setiap kegiatan yang dilakukan di dalam perusahaan, serta untuk memberikan pertanggungjawaban kepada shareholders dan stakeholders yang berlandaskan pada peraturan perundangundangan dan nilai-nilai etika. Seperti yang dikemukakan dalam Keputusan Menteri BUMN Nomor 117/2002, mengenai Good Corporate Governance (GCG) yaitu:

1. Transparency (Keterbukaan) Keterbukaan dalam melaksanakan proses pengambilan keputusandan keterbukaan dalam mengemukakan informasi materiil dan relevan mengenai efektif.

2. Accountability (Akuntabilitas) Kejelasan fungsi, pelaksanaan dan pertanggungjawaban organ perseroan sehingga pengelolaan perusahaan terlaksana secara efektif.

3. Responsibility (Pertanggungjawaban) Kesesuaian dalam pengelolaan perusahaan terhadap peraturan perundang-undangan yang berlaku dan prinsip-prinsip korporasi yang sehat.

4. Independency (Kemandirian) Suatu keadaan dimana perusahaan dikelola secara profesional tanpa benturan kepentingan dan pengaruh/tekanan dari pihak manapun yang tidak sesuai dengan peraturan perundangundangan yang berlaku dan prinsipprinsip korporasi yang sehat.

5. Fairness (Kewajaran) Keadilan dan kesetaraan didalam memenuhi hak-hak stakeholders yang timbul berdasarkan perjanjian dan peraturan perundang-undangan yang berlaku.

Kebanyakan perusahaan yang mencapai kesuksesan/keberhasilan merupakan perusahaan yang memiliki nilai etika pelaksanaan pekerjaan tinggi. Hal tersebut bisa terjadi karena disaat diterapkan nilai etika bisnis tinggi, maka konsumen atau masyarakat lainnya merasa puas sehingga dilain kesempatan mereka bersedia mengikat perikatan bisnis dengan perusahaan tersebut, dengan demikian bisnis perusahaan beretika tinggi tersebut terus berkembang, Ali, (2018).

Kinerja perusahaan merupakan hasil sesungguhnya atau output yang dihasilkan sebuah perusahaan yang kemudian diukur dan dibandingkan dengan hasil atau output yang diharapkan. Perusahaan yang mampu bersaing dan memiliki kinerja yang baik dapat diwujudkan dengan mengimplementasikan penerapan Business Ethic dan Good Corporate Governance (GCG) yang dapat dilihat dari salah satu tujuan penting di dalam mendirikan 
sebuah perusahaan yaitu, untuk meningkatkan kesejahteraan semua elemen dari perusahaan termasuk di dalamnya karyawan, Amri (2016). Hal ini disebabkan karena good corporate governance dapat mendorong terbentuknya pola kerja manajemen yang bersih, transparan, dan professional, Wati (2012).

\section{METODE PENELITIAN}

Metode penelitian yang digunakan adalah deskriptif. Penulisan deskriptif, yaitu penulisan yang berusaha untuk menuturkan pemecahan masalah yang ada sekarang berdasarkan data-data, menyajikan data, menganilisis dan menginterpretasi. Penulisan deskriptif bertujuan membuat deskripsi secara sistematis, faktual, dan akurat tentang faktafakta dan sifat-sifat populasi atau objek tertentu. Dalam hal ini penulis menggambarkan suatu gejala yang sedang terjadi berdasarkan indikator-indikator tertentu dari konseptual yang dioperasionalkan, dan tidak bermaksud menjelaskan suatu hubungan antarvariabel. Pada kesempatan kali ini penulis akan membahas tentang Business Ethic \& Good Corporate Governance (GCG pada PT Bank Danamon Indonesia Tbk.

\section{HASIL DAN PEMBAHASAN}

Dalam menjalankan pekerjaannya, manajemen dan pekerja diwajibkan menerapkan etika bisnis yang merupakan penjabaran nilai budaya perusahaan yang selaras dengan Visi dan Misi Perusahaan.

1. Etika Pribadi

a. Penampilan dan cara berpakaian Manajemen dan Pekerja harus mencerminkan nilai profesional dan menjaga etika dalam berpenampilan.

b. Manajemen dan Pekerja dilarang bertindak atau mengeluarkan kata-kata kasar, kotor, mengarah pada kekurangan fisik, SARA, atau yang dapat digolongkan mengumpat, memaki, baik dalam bahasa Indonesia atau bahasa lain secara emosional dan tidak profesional, demi menjaga lingkungan kerja yang harmonis. Hal ini termasuk melalui media informasi formal seperti email/ surat/ memo/ media sosial/ media cetak.

c. Manajemen dan Pekerja tidak diperkenankan untuk mengadakan atau ikut serta dalam segala bentuk judi dan lotere di lingkungan kerja Perusahaan. Manajemen dan Pekerja tidak diperkenankan memakai sistem dan peralatan yang berada di Perusahaan untuk kegiatan-kegiatan tersebut.

d. Manajemen dan Pekerja dilarang mabuk atau minum minuman keras yang memabukkan di lingkungan kerja, dilarang menyimpan/menyalahgunakan/ menggunakan dan/atau mengedarkan narkotika, psikotropika, obat-obatan terlarang dan zat adiktif/perangsang lainnya di lingkungan kerja.

e. Manajemen dan Pekerja dilarang menyimpan/ membawa senjata api/ senjata berbahaya lain dalam lingkungan kerja, kecuali Manajemen dan Pekerja yang ditunjuk oleh Perusahaan dan dilaksanakan sesuai dengan ketentuan yang berlaku.

2. Etika dengan Nasabah

a. Manajemen dan Pekerja wajib melayani setiap nasabah secara profesional dengan sikap sopan, ramah dan wajar.

b. Manajemen dan Pekerja harus tanggap dan berusaha memahami kebutuhan serta mencarikan alternatif solusi atas masalah nasabah dengan sebaik-baiknya dan 
dengan tetap memperhatikan kepentingan Perusahaan dan peraturan perundangan yang berlaku.

c. Ketepatan dan efisiensi waktu pelayanan adalah faktor yang mendukung layanan yang berkualitas.

d. Dalam memberikan pelayanan kepada nasabah, Manajemen dan Pekerja tidak boleh memberikan pelayanan diluar prosedur yang berlaku di Perusahaan, termasuk namun tidak terbatas kepada memberikan pinjaman kepada nasabah secara pribadi dan sebaliknya dan/atau memberikan nasehat keuangan kecuali diberi kewenangan oleh Perusahaan sebagai bagian dari tanggung jawab pekerjaannya.

3. Etika Dengan Pihak Ketiga

a. Dalam memilih supplier/vendor/perusahaan alih daya yang berfungsi sebagai rekanan/mitra, Manajemen dan Pekerja wajib memperhatikan prinsip-prinsip efisiensi, efektif, kompetitif, transparan, adil dan akuntabel.

b. Manajemen dan Pekerja harus memastikan bahwa supplier/vendor/perusahaan alih daya/pekerja alih daya memahami dan mematuhi Kode Etik dan kebijakan Perusahaan yang terkait.

c. Manajemen dan Pekerja wajib memastikan bahwa kerjasama yang dilakukan dengan supplier/vendor memiliki perjanjian tertulis dan nilai transaksi yang wajar.

4. Etika dengan Regulator

a. Perusahaan berkomitmen mematuhi peraturan perundang-undangan yang berlaku. Untuk itu, Manajemen dan Pekerja wajib untuk mempelajari, memahami dan mentaati setiap peraturan perundang-undangan yang berlaku.

b. Manajemen dan Pekerja juga wajib membina hubungan dan komunikasi yang baik dengan Regulator.

5. Etika antara Manajemen dan Pekerja

a. Hubungan antara Manajemen dan Pekerja dilandasi sikap kerjasama, saling menghargai dan menghormati sesuai dengan nilai-nilai Perusahaan.

b. Perusahaan berkomitmen untuk memberikan kesempatan yang sama di semua aspek berkaitan dengan pekerjaan.

c. Perusahaan tidak mentolerir setiap diskriminasi termasuk namun tidak terbatas kepada ras, warna kulit, agama, jenis kelamin, asal negara, status sosial, cacat fisik, dan status perkawinan.

d. Perusahaan melarang segala bentuk pelecehan seksual (sexual harassment) dan perbuatan memfitnah, menyerang, menganiaya, mengancam atasan atau sesama Pekerja dan/ atau keluarganya. Termasuk semua bentuk pelecehan/fitnah baik yang dilakukan secara lisan maupun tulisan secara tertulis melalui segala bentuk termasuk namun tidak terbatas pada email, media elektronik, media sosial, dll.

e. Manajemen dan Pekerja memiliki tanggung jawab untuk menciptakan lingkungan kerja yang positif dan memastikan semua individu diperlakukan secara terhormat dan bermartabat.

f. Manajemen dan Pekerja dalam memutuskan hal yang terkait dengan pekerjaan harus dilakukan secara profesional dan tanggung jawab sesuai nilai-nilai budaya Perusahaan.

g. Manajemen dan Pekerja wajib menjalankan pekerjaan berdasarkan kewenangan yang dimilikinya dengan penuh tanggungjawab dan kehati-hatian. 
h. Manajemen dan Pekerja tidak diperkenankan saling meminjam dan/atau meminjamkan uang dan/atau bentuk lainnya yang dapat mempengaruhi profesionalisme dalam bekerja.

i. Perusahaan memiliki kewenangan mutlak untuk memberikan pekerjaan, penugasan, dan/atau melakukan mutasi kepada Manajemen dan Pekerja sesuai dengan kebijakan yang berlaku.

6. Pemberian dan Penerimaan Hadiah dan Perjamuan

a. Manajemen dan Pekerja dilarang memberi atau menerima segala bentuk hadiah dan/atau perjamuan kepada/dari pihak-pihak lain sebagai bentuk balas jasa dan/atau ungkapan simpati antar pribadi terkait dengan pekerjaan dan/atau jabatannya.

b. Dalam hal Manajemen dan Pekerja menerima hadiah dan/atau perjamuan dan karena beberapa sebab sulit untuk dikembalikan, maka Manajemen dan Pekerja wajib untuk melaporkan kepada Perusahaan.

c. Pemberian hadiah dan/atau perjamuan (entertainment) hanya dapat dilakukan oleh Manajemen dan Pekerja yang ditunjuk oleh Perusahaan untuk membina hubungan baik (goodwill) dan dilaksanakan sesuai dengan ketentuan yang berlaku serta tidak bertentangan dengan nilai-nilai Perusahaan.

7. Perlindungan dan Penggunaan Fasilitas Nasabah, Relasi dan Rekanan

a. Manajemen dan pekerja tidak diperkenankan memakai atau menerima fasilitas milik nasabah, relasi, dan atau rekanan dan tidak diperkenankan mendapat atau meminta pinjaman atau dalam bentuk lainnya dari mereka untuk kepentingan pribadi.

b. Larangan ini dimaksudkan agar manajemen dan pekerja dapat bersikap tegas dalam pengambilan keputusan berdasarkan peraturan/ketentuan yang ada sesuai dengan wewenang dan tanggung jawab yang telah dilimpahkan kepadanya.

8. Penyuapan dan Korupsi

a. Perusahaan melarang penyuapan dan korupsi dalam bentuk apapun.

b. Penyuapan adalah usaha yang dilakukan oleh pihak-pihak lain kepada manajemen dan pekerja dan/atau sebaliknya dengan tujuan mempengaruhi pengambilan keputusan dan dilakukan semata-mata demi kepentingan/ keuntungan pribadi kedua belah pihak yang bertentangan dengan hukum dan peraturan perundang-undangan yang berlaku.

c. Yang termasuk penyuapan adalah penerimaan maupun pemberian imbalan atau janji-janji dalam arti seluas-luasnya, baik berupa uang, barang, jasa, fasilitasfasilitas atau kemudahan-kemudahan lainnya, dengan dan/atau tanpa melalaikan prosedur dan hukum yang berlaku dalam penyelesaian suatu urusan.

9. Etika dengan Pesaing, Dalam pelaksanaan bisnis dan operasional sehari-hari, hubungan dengan pesaing menjadi sesuatu yang sulit dihindari baik dalam persaingan bisnis maupun dalam suatu kerjasama atau pertukaran informasi. Untuk itu perlu diperhatikan hal-hal sebagai berikut:

a. Melaksanakan prinsip kehati-hatian dan etika berkomunikasi yang baik;

b. Tidak mencemarkan nama baik pesaing, perusahaan lain, organisasi lain atau negara.

c. Memastikan kepatuhan terhadap kebijakan dan pedoman keamanan informasi.

d. Memastikan pertukaran informasi tidak menghasilkan kolusi. 
Perusahaan menghormati dan mentaati undang-undang tentang anti monopoli yang mendukung iklim persaingan bisnis yang sehat dan kompetitif serta selalu melindungi kepentingan nasabah dari segala praktek bisnis yang tidak wajar. Manajemen dan Pekerja wajib mempelajari, memahami, mentaati, dan melaksanakan Kode Etik dan melaporkan kepada Perusahaan apabila terjadi suatu pelanggaran maupun percobaan pelanggaran terhadap Kode Etik. Manajemen dan Pekerja wajib menyusun pernyataan tahunan, yang berkaitan dengan pelaksanaan Kode Etik, yang memuat antara lain:

1. Hubungan atau kepentingan yang terindikasi menimbulkan benturan dengan kepentingan Perusahaan

2. Hubungan keluarga dan/atau perkawinan

3. Aktivitas diluar Perusahaan; dan/atau

4. Penerimaan hadiah/perjamuan.

5. Keamanan informasi

Sebagai wujud komitmen Perusahaan untuk terus melaksanakan penerapan prinsip tata kelola yang baik secara konsisten dan berkesinambungan, Perusahaan menerapkan sistem pelaporan pelanggaran dalam rangka memberikan kesempatan kepada Manajemen, Pekerja, nasabah dan pihak ketiga untuk menyampaikan laporan mengenai dugaan pelanggaran terhadap prinsip tata kelola Perusahaan yang baik serta nilai etika yang berlaku, berdasarkan bukti dan niat baik untuk kepentingan Perusahaan. Dengan adanya kebijakan ini, tidak ada Manajemen dan Pekerja yang dapat menggunakan jabatan mereka untuk mencegah seseorang untuk membuat laporan. Dalam hal manajemen dan/atau pekerja berdasarkan peran mereka di perusahaan mengetahui identitas whistleblower, mereka harus memastikan bahwa identitas tersebut tidak diketahui oleh siapa pun yang tidak memiliki kewenangan untuk menerima informasi tersebut. Berikut adalah pelanggaran terhadap Kode Etik, diantaranya:

1. Ketidakpatuhan terhadap Kode Etik ini akan dikenakan tindakan disiplin sesuai dengan ketentuan Perusahaan yang berlaku dan termasuk dapat dikenakan sanksi berdasarkan hukum perdata maupun pidana sesuai dengan prosedur dan ketentuan yang berlaku.

2. Dalam hal Manajemen dan Pekerja melakukan pelanggaran berat atas Kode Etik ini, maka Manajemen dan Pekerja bersedia untuk dilakukan pengakhiran hubungan kerja sesuai dengan kebijakan di Perusahaan.

3. Manajemen dan Pekerja yang mengetahui pelanggaran atau percobaan pelanggaran Kode Etik tapi tidak melaporkannya, dianggap melanggar Kode Etik.

PT Bank Danamon Indonesia Tbk merupakan perusahaan terbuka, yang harus mematuhi Undang-Undang Perseroan Terbatas, regulasi Bank Indonesia, Pasar Modal dan Otoritas Jasa Keuangan (OJK), International Finance Standard (IFRS), Standar Akunting Keuangan Indonesia, Standar Internasional untuk Praktik Profesional Internal Audit, Kerangka Kerja COSO dan ASEAN Corporate Governance Scorecard. PT Bank Danamon Indonesia Tbk terus mengadopsi pentingnya struktur tata kelola yang transparan dan dengan bangga dapat menyatakan bahwa Danamon telah menerapkan prinsip-prinsip yang berlaku dan praktik terbaik.

Kerangka kerja tata kelola perusahaan PT Bank Danamon Indonesia Tbk. telah dirancang untuk mencapai sukses jangka panjang dengan menjadi bank terbaik bagi nasabah dan menghasilkan keuntungan yang berkelanjutan bagi para pemegang saham. Bagan berikut menetapkan kerangka tata kelola Perusahaan: 


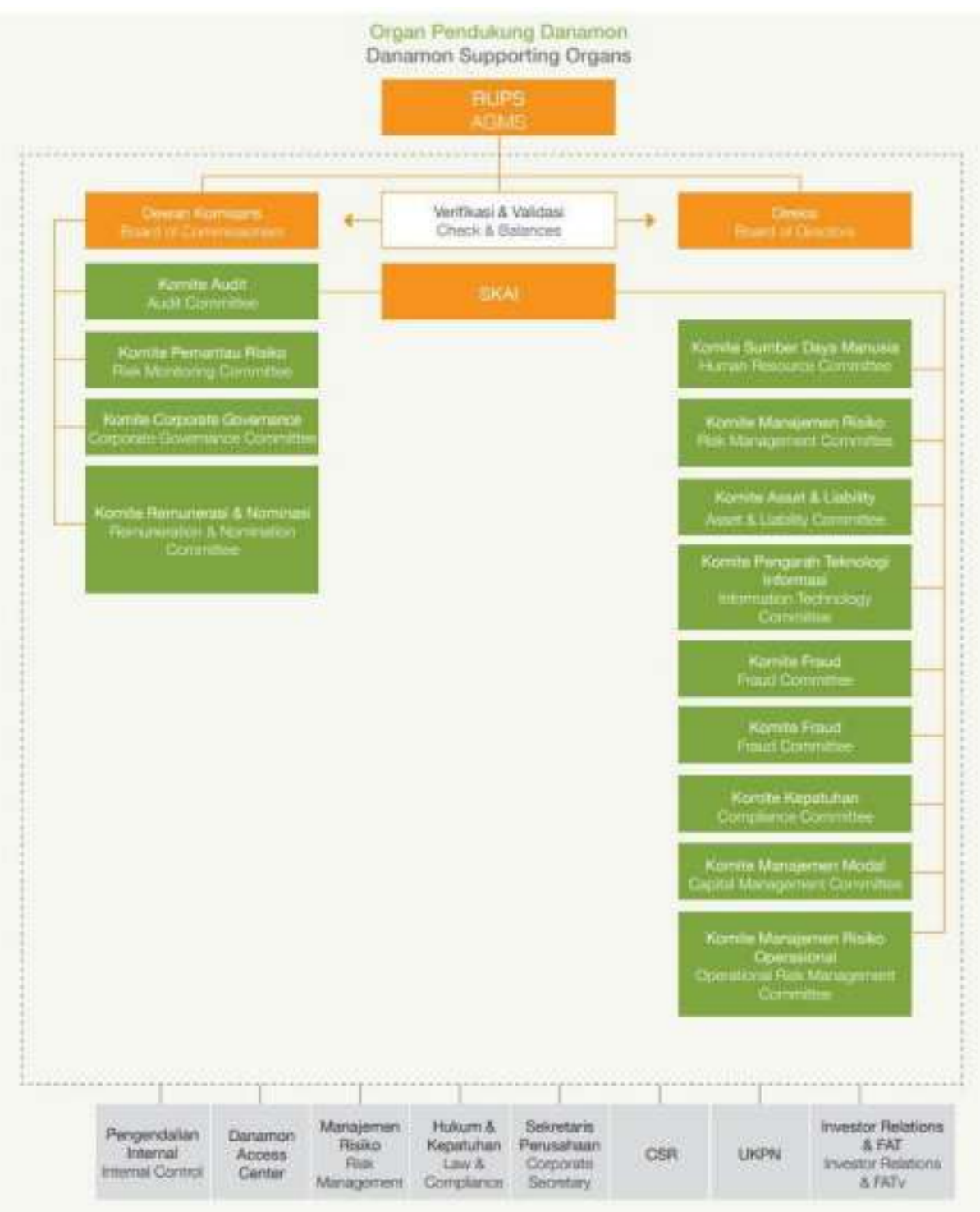

Mengingat peran sosial dan ekonomi yang signifikan, kepatuhan pada peraturan merupakan hal yang wajib bagi sektor keuangan mana pun di seluruh dunia. Semenjak awal PT Bank Danamon Indonesia Tbk sebagai lembaga keuangan telah mengintegrasikan prinsipprinsip Good Corporate Governance. Standar Kepatuhan ini menjadi dasar dalam produk dan layanan yang diberikan kepada nasabah. PT Bank Danamon Indonesia Tbk percaya budaya kepatuhan yang kuat akan memberikan kekuatan untuk mencapai keberhasillan usaha. Dan PT Bank Danamon Indonesia Tbk menyadari bahwa kepatuhan adalah tanggung jawab setiap individu di PT Bank Danamon Indonesia Tbk.

Isu penting dari budaya kepatuhan di bank adalah penipuan dan korupsi. PT Bank Danamon Indonesia Tbk telah mengembangkan program "zero tolerance for fraud". Strategi Anti-Fraud Danamon mencakup proses-proses yang saling berkaitan, yaitu tahap Pencegahan Penipuan, Deteksi, Investigasi dan Pencegahan. Program ini telah sepenuhnya disosialisasikan kepada seluruh karyawan di semua unit bisnis dan daerah operasional. Setiap tuduhan dan laporan kasus diselidiki secara menyeluruh dan personil yang terkait akan di disiplinkan sesuai dengan peraturan dan kebijakan Perusahaan. Dalam rangka meningkatkan efektivitas sistem pemantauan penipuan dan implementasi GCG, PT Bank Danamon Indonesia Tbk telah membentuk sistem pelaporan pelanggaran yang mendorong 
pengungkapan dan pelaporan fraud. Whistleblowing Channels : Fax: +62 2125505950 ; Email: fraud@danamon.co.id ; Email: whistleblower@danamon.co.id.

Sistem whistleblowing ini sebagai bentuk komitmen Danamon untuk memperkuat integritas, memerangi korupsi dan pelanggaran terkait lainnya. Kebijakan ini mengatur kondisi dan prosedur untuk investigasi dugaan korupsi, penipuan dan setiap pelanggaran lainnya termasuk tindakan seperti yang melibatkan Personil Bank dan/atau Proyek Bank serta tindakan yang mencederai operasional dan misi Bank. Melalui mekanisme ini setiap orang dapat melaporkan dugaan pelanggaran secara rahasia melalui media elektronik seperti email, surat atau secara langsung melalui diskusi tertutup. Danamon juga telah memiliki sebuah sistem Live-Chat yang memungkinkan karyawan untuk bertanya, mengirimkan kritik, pengaduan atau melaporkan langsung kepada Direksi. Kasus yang dilaporkan melalui mekanisme whistleblowing sepanjang tahun 2014 adalah sebagai berikut:

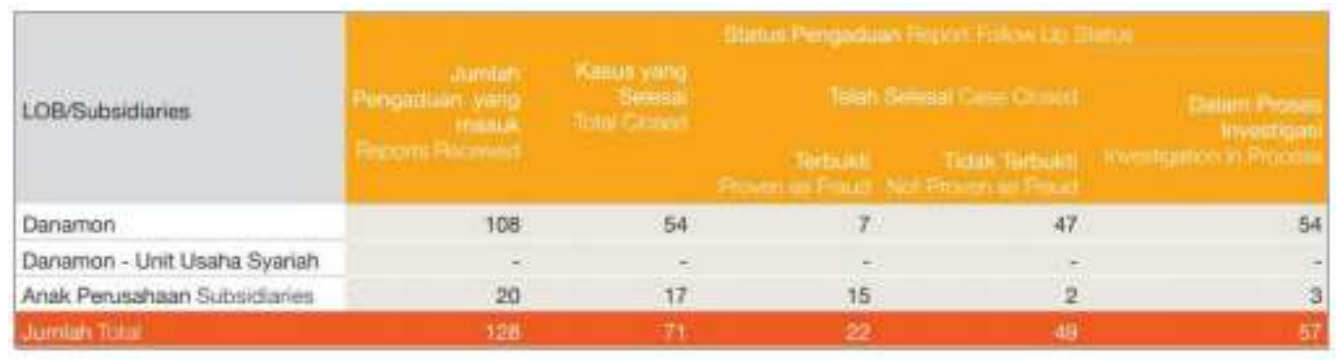

Selain itu, PT Bank Danamon Indonesia Tbk memantau dengan seksama setiap risiko internal fraud di operasional perusahaan. Jumlah kasus fraud yang terjadi sepanjang 2014 dijelaskan dalam ilustrasi berikut:

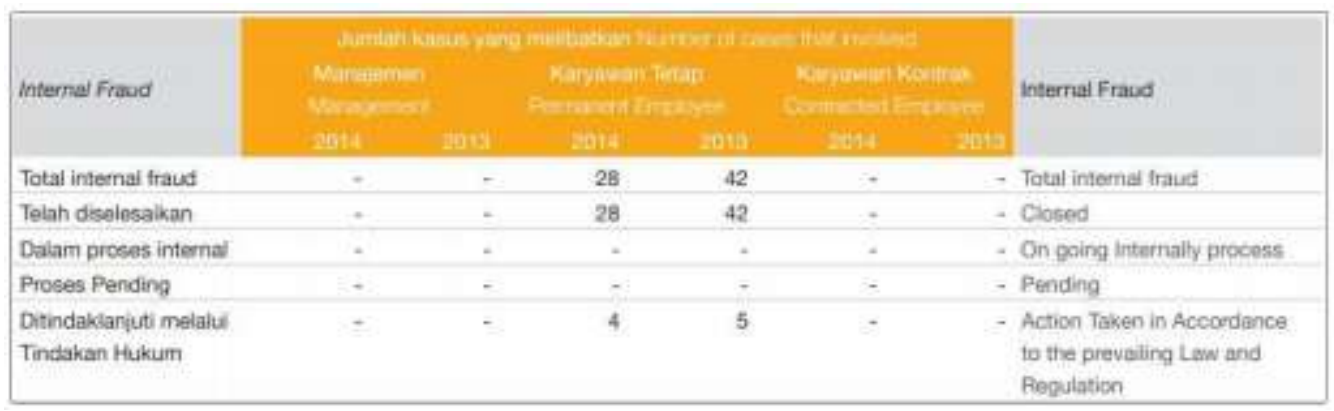

Transparansi dan kepatuhan, PT Bank Danamon Indonesia Tbk mengkaji praktek tata kelola perusahaan sesuai dengan persyaratan yang relevan dari praktik terbaik tata kelola perusahaan internasional dan nasional, termasuk ASEAN Corporate Governance Scorecard dan roadmap dari Otoritas Jasa Keuangan (OJK). Bank melakukan penilaian internal dan eksternal untuk memantau pelaksanaan GCG dari lima prinsip GCG, yaitu transparansi, akuntabilitas, tanggung jawab, independensi, serta keadilan dan kesetaraan.

Bank senantiasa menunjukkan kepatuhan dengan standar tata kelola tingkat nasional, regional dan internasional melalui laporan yang transparan. Selain itu, PT Bank Danamon Indonesia Tbk melaporkan dan menerbitkan Laporan Tahunan dan Laporan Keberlanjutan secara komprehensif. Selain itu, PT Bank Danamon Indonesia Tbk secara berkala melaporkan informasi keuangan dan non-keuangan yang signifikan kepada para pemangku kepentingan melalui publikasi triwulan, paparan publik, laporan keuangan dan laporan lainnya yang disampaikan kepada Bank Indonesia, Pasar Modal dan OJK serta para pemangku kepentingan lainnya sesuai dengan peraturan dan ketentuan yang berlaku. Laporan-laporan ini juga dapat diakses melalui situs Danamon www.danamon.co.id. 
PT Bank Danamon Indonesia Tbk menjamin adanya manajemen dan kontrol dari Bankyang bertanggung jawab dan berbasis nilai melalui sistem manajemen keberlanjutan. PT Bank Danamon Indonesia Tbk telah berkomitmen terhadap standar internasional dan mengadopsi prinsip-prinsip internasional untuk menilai risiko dan meningkatkan dampak positif terhadap kegiatan komersial terhadap lingkungan, dan pembangunan sosial dan ekonomi.

Pedoman Perilaku Bisnis dan Etika Bank serta kebijakan dan pedoman perusahaan mencerminkan komitmen PT Bank Danamon Indonesia Tbk untuk menerapkan berbagai standar, prinsip dan inisiatif eksternal, termasuk dan ISO 22301:2012 dengan standar BCMS (Business Continuity Management System/Sistem Manajemen Kelanjutan Bisnis) yang relevan dengan kegiatan operasional. PT Bank Danamon Indonesia Tbk menjalin kemitraan dengan SGS International dan British Standards Institute (BSI) untuk mengembangkan standar dan menverifikasi proses demi menjamin keberlanjutan operasional dan kepuasan nasabah.

Bank menerapkan berbagai inisiatif untuk meningkatkan standar manajemen risiko. Inisiatif pengembangan produk, proses, dan teknologi informasi perusahaan didukung dan diawasi oleh evaluasi manajemen risiko, termasuk inisiatif yang berkaitan dengan Program Anti Pencucian Uang dan Pemberantasan Pendanaan Terorisme (AML/CFT). Sebagai lembaga keuangan, Danamon menggunakan banyak produk dan jasa yang dibeli dari pemasok pihak ketiga. Dengan demikian, penting bagi PT Bank Danamon Indonesia Tbk untuk memiliki kebijakan pengadaan yang berkelanjutan melalui proses seleksi dan evaluasi supplier (Danamon Supplier Assessment). Bank senantiasa berusaha untuk memilih pemasok yang memenuhi standar sosial dan lingkungan serta pembelian produk yang berkelanjutan. Penilaian PT Bank Danamon Indonesia Tbk terhadap Pemasok memberikan informasi untuk upaya perbaikan, termasuk bagaimana perusahaan dapat bekerja lebih efektif dengan para pemasok sehingga bersama-sama dapat memberikan nilai tambah yang lebih baik.

Pada akhir 2014, Danamon memiliki 468 pemasok terdaftar yang telah disetujui dengan total nilai transaksi pengadaan sebesar lebih dari Rp2,516 miliar (total transaksi PO \& CF, tidak hanya transaksi pengadaan). Profil pemasok PT Bank Danamon Indonesia Tbk sebagai berikut:

\begin{tabular}{|c|c|c|}
\hline Kategon & 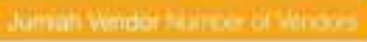 & Catepory \\
\hline IT \& Peralatan Elektronik & 2 & it \& Peripheral \\
\hline Kurit, Perjatanan, Asuransi, Rental & 22 & Courie, Traved, Insuranca, Copy Aertal \\
\hline Signage, Percetakan 8 Promosi & 61 & Sigrage. Printing \& Promotional \\
\hline EO \& Agency/Konsulten & 36 & EO \& Agency/ Consutant \\
\hline Outscurce, Jasa, Lokaai dan Penganglout ATM & 42 & Outsource, Senvices, Premisens \& Maver ATM \\
\hline Alat tulis, Alat Perkantonin, Lisensi & 82 & Office Supplies, Office Equipment, Licensing \\
\hline
\end{tabular}

Seluruh pemasok PT Bank Danamon Indonesia Tbk, termasuk proses yang berkerja sama dengan pihak outsourcing, seperti call center, keamanan, dan para collectors, harus mematuhi kebijakan pengadaan Danamon, yang meliputi kepatuhan terhadap hukum dan peraturan pemerintah Indonesia dan Bank Indonesia yang berlaku, terutama mencakup aspekaspek hak asasi manusia, dan praktik tenaga kerja. Tahun ini PT Bank Danamon Indonesia Tbk menetapkan kebijakan baru yang mengatur mengenai kewajiban vendor dalam mengelola dan meminimalkan dampak operasional mereka terhadap lingkungan sebagai salah satu kriteria seleksi dan evaluasi. 
Danamon Syariah memegang prinsip syariah berdasarkan fatwa yang dikeluarkan oleh Dewan Syariah Nasional Majelis Ulama Indonesia (DSN-MUI) dan peraturan GCG yang diatur dalam peraturan Bank Indonesia. Unit Usaha Syariah Danamon telah melakukan self assessment terhadap penerapan tata kelola perusahaan yang baik dan menerbitkan laporan GCG syariahnya. Tata kelola perusahaan yang baik dalam Perbankan Syariah memiliki prinsip serupa terhadap transparansi, akuntabilitas, tanggung jawab, independensi serta keadilan dan kesetaraan. Pelaksanaan tata kelola perusahaan yang baik dicapai melalui penerapan manajemen risiko berbasis Syariah.

Manajemen risiko harus sesuai dengan rekomendasi Dewan Pengawas Syariah dan hasil pengawasan Bank Indonesia, serta temuan yang disampaikan oleh auditor internal dan eksternal. Anggota Dewan Pengawas Syariah direkomendasikan oleh Dewan Syariah NasionalMajelis Ulama Indonesia (DSN-MUI) dan telah disetujui oleh Bank Indonesia. Pedoman Dewan Pengawas Danamon Syariah dan prosedur operasi standar yang dirinci dalam Pedoman Dewan Pengawas Syariah.

Direktur Unit Usaha Syariah mempunyai tanggung jawab utama, yaitu memastikan bahwa semua aspek manajemen dipantau secara efektif. Direktur Unit Usaha Syariah juga bertanggung jawab atas penerapan prinsip-prinsip GCG dalam semua kegiatan Unit Bisnis Syariah pada setiap tingkat organisasi. Hingga akhir 2014, Danamon merupakan anggota aktif dari asosiasi-asosiasi berikut diantaranya: Asosiasi Emiten Indonesia; Asosiasi Sekretaris Perusahaan Indonesia; dan Perrhimpunan Bank Swasta Nasional (PERBANAS).

\section{KESIMPULAN}

Kode Etik PT Bank Danamon Indonesia Tbk merupakan nilai-nilai etika yang mengacu kepada visi, misi dan nilai-nilai budaya perusahaan yang dijunjung tinggi oleh perusahaan. Kode Etik bertujuan untuk menjadi pedoman dalam berperilaku bagi seluruh Manajemen dan Pekerja PT Bank Danamon Indonesia Tbk dalam melaksanakan tugasnya sehari-hari, menjalin hubungan dengan nasabah, rekan sekerja dan pihak ketiga. Manajemen dan Pekerja wajib mempelajari, memahami, mentaati, dan melaksanakan Kode Etik dan melaporkan kepada Perusahaan apabila terjadi suatu pelanggaran maupun percobaan pelanggaran terhadap Kode Etik. Penerapan Etika bisnis dan Good Corporate Governance (GCG) yang baik merupakan keharusan dan landasan penting bagi keberhasilan mewujudkan visi dan misi serta kelangsungan usaha perusahaan.

Pelaksanaan prinsip-prinsip Etika Bisnis dan Good Corporate Governance (GCG) dianggap bisa membawa dampak positif terhadap keberlanjutan perusahaan. Kerangka kerja tata kelola perusahaan PT Bank Danamon Indonesia Tbk. telah dirancang untuk mencapai sukses jangka panjang dengan menjadi bank terbaik bagi nasabah dan menghasilkan keuntungan yang berkelanjutan bagi para pemegang saham. Manajemen risiko yang efektif merupakan dasar dari kemampuan perusahaan untuk menghasilkan keuntungan secara konsisten dan berkelanjutan. PT Bank Danamon Indonesia Tbk melakukan semua bisnis dalam kerangka kerja manajemen risiko yang menyeluruh. PT Bank Danamon Indonesia Tbk berkomitmen untuk melakukan pendekatan yang bijaksana dan kuat yang menyokong janji PT Bank Danamon Indonesia Tbk kepada para pemegang saham, nasabah dan rekan kerja, terutama untuk memberikan keamanan dan keselamatan bagi para pemangku kepentingan. 


\section{DAFTAR RUJUKAN}

Ali, Hapzi .2018. Modul BE \& GG. Univeristas Mercu Buana. Jakarta

Amri, S., Haryono, A. T., \& Warso, M. M. (2016). Pengaruh Good Corporate Governance terhadap Kinerja Karyawan PT Aditec Cakrawiyasa Semarang. Journal of Management, 02 (2).

Danamon. 2019. www.danamon.co.id. (20 Oktober 2019, Jam 19.00).

Floyd, L. A., Xu, F., Atkins, R., \& Caldwell, C. (2013). Ethical outcomes and business ethics: Toward improving business ethics education: JBE JBE. Journal of Business Ethics, 117(4), 753-776. doi:http://dx.doi.org/10.1007/s10551-013-1717-z

Magnis Suseno (1989). Monks, R. A. G., \& Minow, N. (2003). Corporate governance. New Jersey: Blackwell.

Muchtar, S., \& Darari, E. (2013). Pengaruh Corporate Governance terhadap Kinerja Perusahaan Manufaktur yang terdaftar di Bursa Efek Indonesia. Financing and Banking, 15 No.2.

Muchlisin, Riadi. 2016. https://www.kajianpustaka.com/2016/10/pengertian-prinsipdanmanfaat-etika-bisnis.html. (10 Oktober 2019, Jam 15.00).

Nasution, Marihot dan Dodi Setiawan. 2007. Pengaruh Corporate Governance terhadap Manajemen Laba di Industri Perbankan Indonesia. Simposium Nasional Akuntansi 10. Makasar tanggal $26-28$ Juli.

Wati, L. M. (2012). Pengaruh Praktek Good Corporate Governance terhadap Kinerja Kuangan Perusahaan di Bursa Efek Indonesia. Jurnal Manajemen, 01 (1). 